\title{
Changes in isoproterenol-stimulated adenylate cyclase activity in rat testicular tissue during cryptorchidism and after orchidopexy
}

\author{
T. Jahnsen*, B. Karpe†, H. Attramadal*, M. Ritzén $\ddagger$ and V. Hansson* $\S$
}

*Institute of Pathology, Rikshospitalet, Oslo 1, Norway; †Department Pediatric Surgery, St Goran Hospital, 1128I Stockholm, Sweden; $\ddagger$ Pediatric Endocrinology Unit, Karolinska Hospital, 1040I Stockholm, Sweden; and §Institute of Medical Biochemistry, University of Oslo, Blindern, Oslo 3, Norway

\begin{abstract}
Summary. Cryptorchidism was associated with increased responsiveness of the isoproterenol-sensitive adenylate cyclase in membrane particles from rat testis. Abdominal testes from uni- and bilaterally cryptorchid rats showed the same activities. The change in isoproterenol-responsive adenylate cyclase was independent of the age at which the animals were made cryptorchid. The isoproterenol response was maximal 3-4 weeks after the rats were made cryptorchid. By 2-3 months after orchidopexy the isoproterenol response in the rat testis had decreased to normal control values.
\end{abstract}

\section{Introduction}

$\beta$-Adrenergic agonists cause their physiological effects by activating adenylate cyclase (EC 4.6.1.1) and thereby increasing intracellular levels of cyclic AMP (cAMP) (Sutherland \& Rall, 1960). Isoproterenol can stimulate cAMP secretion by cultured Sertoli cells (Verhoeven, Dierickx \& de Moor, 1979; Verhoeven, 1980; Verhoeven, Cailleau \& de Moor, 1980; Heindel, Steinberger \& Strada, 1981 ), indicating that these cells contain $\beta$-adrenergic receptors coupled to the adenylate cyclase. This has been confirmed by direct measurements of the adenylate cyclase activities in membrane preparations (Jahnsen, Verhoeven, Purvis, Cusan \& Hansson, 1982). In addition, rat Leydig cells probably also possess $\beta$-adrenergic receptors since isoproterenol activates adenylate cyclase activity in rat tumour Leydig cells ( $\mathrm{T}$. Jahnsen, unpublished data).

Jahnsen, Gordeladze, Haug \& Hansson (1981) have shown that there is a selective decrease in the gonadotrophin-stimulated adenylate cyclase activity in the abdominal testes of unilaterally cryptorchid rats. This knowledge, together with preliminary data showing that cryptorchidism was associated with increased isoproterenol response in testicular tissue, prompted more detailed studies of isoproterenol responsive adenylate cyclase during cryptorchidism and after orchidopexy.

\section{Materials and Methods}

Animals. The results in this paper are from two experiments.

In Exp. I, 30 male Sprague-Dawley rats were used. Rats in groups of 5 were sham-operated or made unilaterally or bilaterally cryptorchid at 20 or 80 days of age. The animals were killed 4 weeks later. 
In Exp. II, 72 male Sprague-Dawley rats (6/group) were used at 17 days of age: rats in 4 groups were subjected to sham-operations, rats in 7 groups were made bilaterally cryptorchid and those in the final group were killed at the beginning of the experiment. At 34 days of age one sham-operated and one bilaterally cryptorchid group of rats were killed. Simultaneously, 3 groups of control rats and 3 cryptorchid groups were sham-operated, whereas the remaining 3 groups of rats were surgically treated by orchidopexy as previously described (Karpe, Pløen, Hagenäs \& Ritzén, 1981). At 42, 59 and 120 days of age, one group each of control, cryptorchid and surgically treated animals was killed. Surgical techniques and treatment of the animals were as described previously (Jahnsen et al., 1981; Karpe et al., 1981). The testes were weighed, frozen in liquid nitrogen and stored at $-70^{\circ} \mathrm{C}$ until assayed for isoproterenol-responsive adenylate cyclase.

Preparation of particulate fraction. Testicular tissue was homogenized in TE buffer (10 mM Tris$\mathrm{HCl}, 1 \mathrm{~mm}$-EDTA, $\mathrm{pH} \mathrm{7.4)}$, and the homogenates were centrifuged at $27000 \mathrm{~g}$ for $30 \mathrm{~min}$ at $0-4^{\circ} \mathrm{C}$. The pellets (particulate fractions) were resuspended in TE buffer containing $0.1 \%$ bovine serum albumin, and $20 \mu \mathrm{l}(25-35 \mu \mathrm{g}$ protein) per assay tube were used for measuring adenylate cyclase activity.

Adenylate cyclase assay. The assay of particulate adenylate cyclase activity in rat testicular tissue has been described previously (Jahnsen, Purvis, Birnbaumer \& Hansson, 1980a; Jahnsen, Gordeladze, Torjesen \& Hansson, 1980b). In brief, particulate fractions ( $20 \mu 1)$ from whole testis tissue were examined for adenylate cyclase activity in a final volume of $50 \mu$ l. Each assay tube contained 0.8 mM-ATP (Exp. I), 0.5 mM-ATP (Exp. II) (including $2 \times 10^{6}-4 \times 10^{6}$ c.p.m. [ $\alpha$ ${ }^{32}$ P]ATP), 0.04 mM-GTP (Exp. I), 0.02 mM-GTP (Exp. II), $3.0 \mathrm{~mm}-\mathrm{MgCl}_{2}, 1 \mathrm{~mm}$-cAMP (including 6000-8000 c.p.m. $\left[8-{ }^{3} \mathrm{H}\right]$ cAMP), 1 mM-EDTA and ATP-regenerating system. If not otherwise stated, the incubations were carried out in the absence or presence of isoproterenol (Isoprenalin; NAF-Laboratoriene A/S, Oslo, Norway), $5 \mu \mathrm{g} / \mathrm{ml}$, at $35^{\circ} \mathrm{C}$ for $12 \mathrm{~min}$. The reactions were stopped with $0.1 \mathrm{ml}$ of a solution containing $10 \mathrm{mM}-\mathrm{cAMP}, 40 \mathrm{mM}-\mathrm{ATP}$, and $1 \%$ sodium dodecylsulphate followed by mixing and immediate cooling to $0^{\circ} \mathrm{C}$. Cyclic AMP was isolated by combined Dowex 50 and alumina chromatography (Salomon, Londos \& Rodbell, 1974), with the modifications described by Birnbaumer, Yang, Hunzicker-Dunn, Bockaert \& Duran (1976).

The protein contents of the membrane particle suspensions were measured by the technique of Lowry, Rosebrough, Farr \& Randall (1951). The ATP and GTP concentrations used were calculated by u.v.-light spectrophotometry at $260 \mathrm{~nm}$.

Statistics. Statistical analysis of the data was performed using Wilcoxon's two-sample rank test (two-tailed test) and analysis of variance (one way).

\section{Results}

Table 1 summarizes the effects of unilateral and bilateral cryptorchidism on testicular weights (Exp. I). There was marked reduction in testicular weight of the abdominal testes after 4 weeks of cryptorchidism $(P<0.01)$. There was no significant difference between the testicular weight of the abdominal testes from unilaterally and bilaterally cryptorchid rats. The mean weights of the scrotal testis in unilaterally cryptorchid rats were slightly higher than those of control rats.

Text-figure 1 shows the isoproterenol-responsive adenylate cyclase activities in the same animals. There was no difference in cAMP production per $\mathrm{mg}$ protein between control testes and the scrotal testes from unilaterally cryptorchid rats or between abdominal testes from unilaterally and bilaterally cryptorchid rats. The relative response (stimulated adenylate cyclase activity divided by basal adenylate cyclase activity) due to isoproterenol stimulation increased from approximately 2.0 in control testes to approximately 3.0 in abdominal testes. This happened in spite of increased basal activities in the abdominal testes. When cAMP production was expressed 
Table 1. Testicular weights (g), 4 weeks after surgery, in the control, unilaterally and bilaterally cryptorchid rats in Exp. I

\begin{tabular}{|c|c|c|}
\hline & \multicolumn{2}{|c|}{ Age at operation } \\
\hline & 20 days & 80 days \\
\hline Control & $1.42 \pm 0.20$ & $1.91 \pm 0.10$ \\
\hline \multicolumn{3}{|l|}{ Unilateratly cryptorchid rats } \\
\hline Scrotal testis side & $1.54 \pm 0.05$ & $2 \cdot 14 \pm \theta \cdot 07^{*}$ \\
\hline Abdominal testis side & $0.35 \pm 0.02^{*}$ & $0.57 \pm 0.14^{*}$ \\
\hline Bilaterally cryptorchid rats & $0.37 \pm 0.06^{*}$ & $0.63 \pm 0.03^{*}$ \\
\hline
\end{tabular}

Values are mean \pm s.d. for 5 rats/group.

* Values significantly different from the control value : $P<0.01$ (Wilcoxon's rank test).

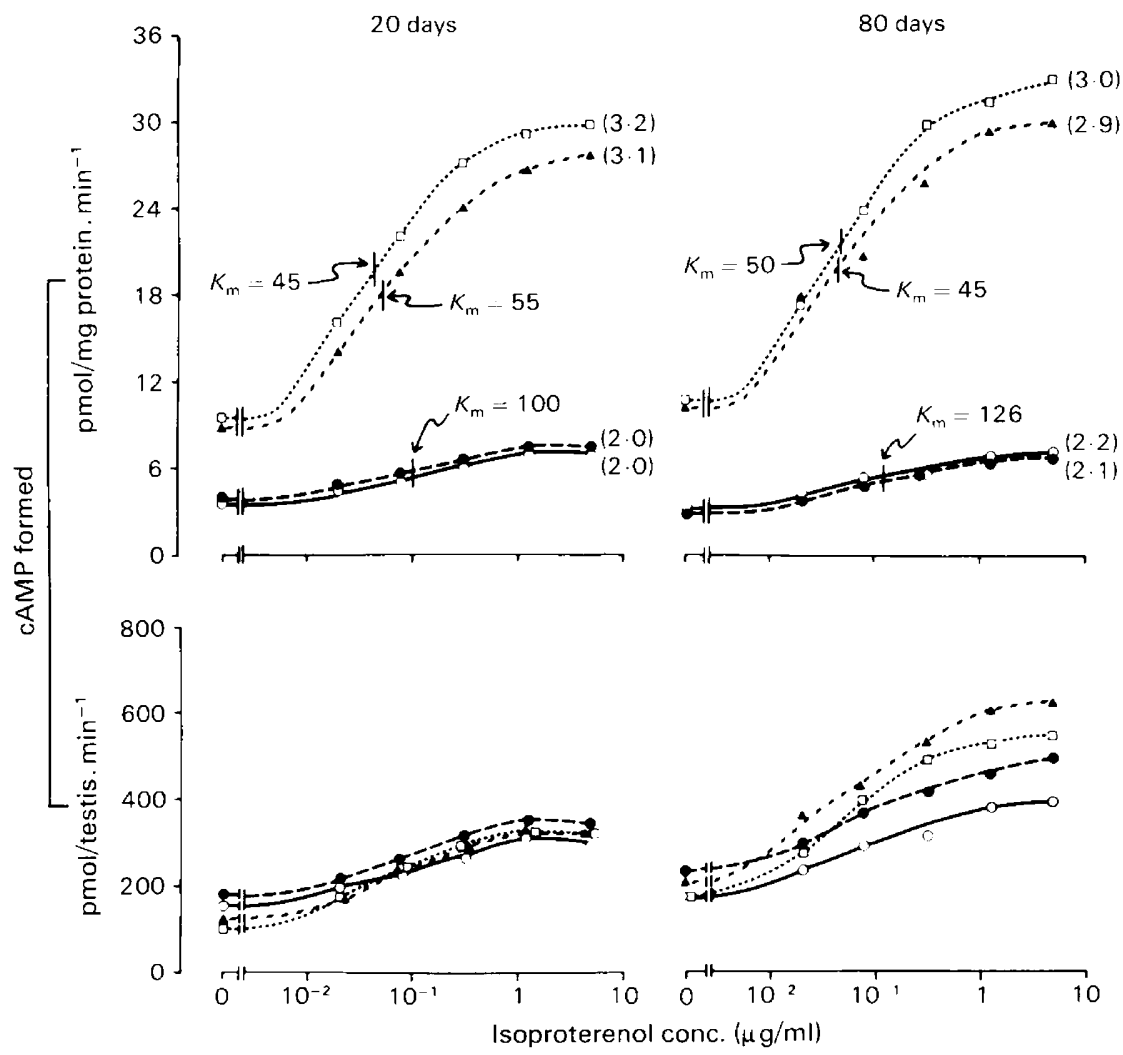

Text-fig. 1. Dose-response curves showing isoproterenol-stimulated adenylate cyclase activity in testicular membrane particles from control $(\mathrm{O}-\mathrm{O})$, unilaterally (scrotal testis, - - abdominal testis, $\square \cdots \cdots$ ) and bilaterally $(\boldsymbol{\Lambda}---\mathbf{\Lambda})$ cryptorchid rats. The age of the animals at operation was 20 or 80 days; the animals were killed 4 weeks later. Each point represents the mean of duplicate determinations from a pool of 5 rats. The numbers in parentheses indicate the maximal relative response. The $K_{\mathrm{m}}$ values indicate the concentration of isoproterenol ( $\mathrm{ng} / \mathrm{ml}$ ) giving $50 \%$ maximal response.

per testis, the differences seen in absolute activities between control and abdominal testes were more or less abolished.

Tables 2 summarizes the effects of cryptorchidism and orchidopexy on testicular weights, basal and isoproterenol-stimulated adenylate cyclase activities in Exp. II. Cryptorchidism caused a 
reduction in testicular weight, but values recovered almost to control levels by 3 months after orchidopexy. Basal and isoproterenol-stimulated adenylate cyclase activities per $\mathrm{mg}$ protein decreased with increasing age in control rat testes and in testes from rats that were surgically treated by orchidopexy, while they increased in bilaterally cryptorchid rats (Table 2).

Table 2. Testicular weights, basal and isoproterenol-stimulated adenylate cyclase activities in testicular membrane particles from control, bilaterally cryptorchid and orchidopexy rats in Exp. II

\begin{tabular}{|c|c|c|c|c|}
\hline & $\begin{array}{c}\text { Age } \\
\text { (days) }\end{array}$ & Control rats & $\begin{array}{l}\text { Bilaterally } \\
\text { cryptorchid } \\
\text { rats }\end{array}$ & $\begin{array}{l}\text { Orchidopexic } \\
\text { rats }\end{array}$ \\
\hline Testicular weights (g) & $\begin{array}{r}17 \\
34 \\
42 \\
59 \\
120\end{array}$ & $\begin{array}{l}0.10 \pm 0.01 \\
0.49 \pm 0.02 \\
0.90 \pm 0.03 \\
1.46 \pm 0.03 \\
1.64 \pm 0.09 \\
(P<0.01)\end{array}$ & $\begin{array}{l}0.33 \pm 0.04^{*} \\
0.33 \pm 0.03^{*} \\
0.34 \pm 0.02^{*} \\
0.31 \pm 0.03^{*}\end{array}$ & $\begin{array}{l}0.43 \pm 0.09^{*} \\
0.97 \pm 0.15^{*} \dagger \\
1.32 \pm 0.35 \dagger \\
(P<0.01)\end{array}$ \\
\hline $\begin{array}{l}\text { Basal adenylate } \\
\text { cyclase activities } \\
\text { (pmol cAMP/mg protein. } \min ^{-1} \text { ) }\end{array}$ & $\begin{array}{r}17 \\
34 \\
42 \\
59 \\
120\end{array}$ & $\begin{array}{c}7.6 \pm 1.4 \\
6.5 \pm 2.5 \\
4.1 \pm 1.0 \\
4.4 \pm 0.5 \\
4.1 \pm 0.4 \\
(P<0.01)\end{array}$ & $\begin{array}{c}5.3 \pm 0.7 \\
7.6 \pm 2.8^{*} \\
6.9 \pm 1.5^{*} \\
11.1 \pm 1.0^{*} \\
(P<0.01)\end{array}$ & $\begin{array}{l}5.9 \pm 2 \cdot 1 \\
4.6 \pm 0.8 \dagger \\
4.5 \pm 0.7 \dagger\end{array}$ \\
\hline $\begin{array}{l}\text { Isoproterenol-stimulated } \\
\text { adenylate cyclase activities } \\
\text { (pmol cAMP/mg protein. } \min ^{-1} \text { ) }\end{array}$ & $\begin{array}{r}17 \\
34 \\
42 \\
59 \\
120\end{array}$ & $\begin{array}{r}11.9 \pm 1.8 \\
10.1 \pm 3.6 \\
6.8 \pm 1.7 \\
6.6 \pm 0.9 \\
7.0 \pm 0.8 \\
(P<0.01)\end{array}$ & $\begin{array}{l}13.0 \pm 1.8 \\
28.3 \pm 9.8^{*} \\
21.3 \pm 3.7^{*} \\
27.2 \pm 2.8^{*} \\
(P<0.01)\end{array}$ & $\begin{array}{l}13.7 \pm 4.5^{*} \dagger \\
8.6 \pm 1.9 \dagger \\
7.4 \pm 0.5 \dagger \\
(P<0.05)\end{array}$ \\
\hline
\end{tabular}

Values are mean \pm s.d. for 6 rats/group.

* Significantly different from value for control rats, $P<0.01$ (Wilcoxon's rank test).

$\uparrow$ Significantly different from value for cryptorchid rats, $P<0.01$ (Wilcoxon's rank test).

The significance levels given in parentheses indicate that the mean values for the rats of different ages in that group are significantly different (one way analyses of variance).

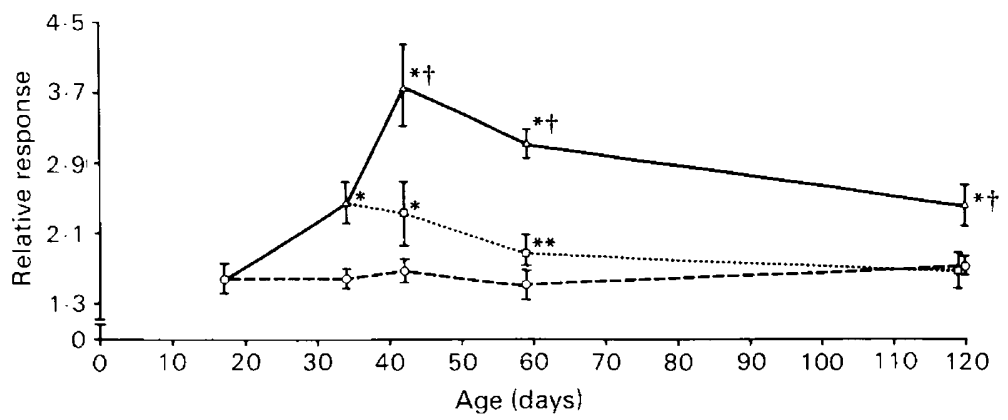

Text-fig. 2. Changes (mean \pm s.d., $n=6$ ) in relative response (stimulated activities divided by basal activities, see Table 2) of isoproterenol-stimulated adenylate cyclase activity in testicular membrane particles from control $\left(\mathrm{O}_{--} \mathrm{O}\right)$, bilaterally cryptorchid $(\triangle-\triangle)$ and orchidopexic $(\square \cdots \square)$ rats. The abscissa shows the age of the animals when killed. ${ }^{*} P<0 \cdot 01,{ }^{* *} P$ $<0.05$ : values for cryptorchid and orchidopexic animals compared with control animals (Wilcoxon's rank test). $\uparrow P<0 \cdot 01$ : values for orchidopexic animals compared with cryptorchid animals (Wilcoxon's rank test). 
The relative response for isoproterenol in testicular tissue from control animals in Exp. II (Textfig. 2) was approximately 1.6 and did not vary with age. This relative response increased in bilaterally cryptorchid rats $(P<0.01)$ and was maximal $(3.8) 3-5$ weeks after the operation. Orchidopexy of animals that had been bilaterally cryptorchid from 17 to 34 days of age showed a gradual decrease $(P<0.01)$ in isoproterenol-responsive adenylate cyclase towards control values. This normalization for the isoproterenol response required $2-3$ months.

\section{Discussion}

The present results show an increased responsiveness of the $\beta$-adrenergic adenylate cyclase system in experimental cryptorchidism and reversal of this effect by orchidopexy. The reason for this increase in isoproterenol response during cryptorchidism is not understood. The increase in basal and isoproterenol-responsive adenylate cyclase activities in the abdominal testis expressed per mg protein can to some extent be explained by the relative enrichment of somatic cells during cryptorchidism, since germ cells do not contain any isoproterenol-responsive adenylate cyclase (unpublished results). However, this cannot explain the increase in relative response.

The increase in isoproterenol response is even more intriguing in light of the fact that the gonadotrophin-stimulated adenylate cyclase reveals a dramatic decrease during cryptorchidism (Jahnsen et al., 1981). The increased relative response to isoproterenol may be explained by an increased number of $\beta$-adrenergic receptors, or improved coupling between the receptor and the adenylate cyclase. However, at present we have not examined $\beta$-adrenergic binding directly.

The fact that an altered response was seen only in the abdominal testis, but not in the scrotal testis from the same animal, indicates that the observed effects are not caused by changes in the levels of circulatory hormones. It may indicate that local factors (temperature, presence of germ cells) may influence the responsiveness of the $\beta$-adrenergic-sensitive adenylate cyclase in the rat testis.

The role of $\beta$-adrenergic agonists for testicular function is not known. Although it appears that isoproterenol stimulates Sertoli cell adenylate cyclase to the same extent as FSH, no physiological data are available to indicate that $\beta$-adrenergic agonists can replace FSH in the initiation of spermatogenesis. Regardless of the physiological implications the results in this study clearly show that cryptorchidism alters isoproterenol-stimulated cAMP production in the rat testis. Surgical treatment by orchidopexy normalizes the elevated response to isoproterenol of the cryptorchid testes.

This study was supported by grants from Norwegian Research Council for Science and the Humanities (NAVF), Swedish Medical Research Council (project 3168), Rockefeller Foundation and The Norwegian Society for Fighting Cancer.

\section{References}

Birnbaumer, L., Yang, P.-C., Hunzicker-Dunn, M., Bockaert, J. \& Duran, J.M. (1976) Adenylyl cyclase activities in ovarian tissues. I. Homogenization and conditions of assay in Graafian follicles and corpora lutea of rabbits, rats and pigs: regulation by ATP, and some comparative properties. Endocrinology 99, 163-184.

Heindel, J.J., Steinberger, A. \& Strada, S.J. (1981) Identification and characterization of a $\beta_{1}$-adrenergic receptor in the rat Sertoli cell. Molec. cell. Endocr. 22, 349-358.

Jahnsen, T., Purvis, K., Birnbaumer, L. \& Hansson, V. (1980a) FSH and $\mathrm{LH} / \mathrm{hCG}$ responsive adenylyl cyclases in adult rat testis: methodology and assay conditions. Int. J. Androl. 3, 396-416.

Jahnsen, T., Gordeladze, J.O., Torjesen, P.A. \& Hansson, V. (1980b) FSH responsive adenylyl cyclase in rat testis. Desensitization by homologous hormone. Archs Androl. 5, 169-177.

Jahnsen, T., Gordeladze, J.O., Haug, E. \& Hansson, V. (1981) Changes in rat testicular adenylate cyclase activities and gonadotrophin binding during unilateral experimental cryptorchidism. J. Reprod. Fert. 63, $381-390$. 
Jahnsen, T., Verhoeven, G., Purvis, K., Cusan, L. \& Hansson, V. (1982) Desensitization of FSH responsive adenylyl cyclase in cultured immature Sertoli cells by homologous hormone. Archs Androl. 8, 205211.

Karpe, B., Pløen, L., Hagenäs, L. \& Ritzén, E.M. (1981) Recovery of testicular functions after surgical treatment of experimental cryptorchidism in the rat. Int. J. Androl. 4, 145-160.

Lowry, O.H., Rosebrough, N.F., Farr, A.L. \& Randall, R.J. (1951) Protein measurement with the folin phenol reagent. J. biol. Chem. 193, 265-275.

Salomon, Y., Londos, C. \& Rodbell, M. (1974) A highly sensitive adenylate cyclase assay. Analyt. Biochem. $58,541-548$.

Sutherland, E.W. \& Rall, T.W. (1960) The relation of adenosine-3',5'-phosphate and phosphorylase to the actions of catecholamines and other hormones. Pharmacol. Rev. 12, 265-299.

Verhoeven, G. (1980) Effects of neurotransmitters and follicle stimulating hormone on the aromatization of androgens and the production of adenosine 3',5' monophosphate by cultured testicular cells. J. Steroid Biochem. 12, 315-322.

Verhoeven, G., Dierickx, P. \& de Moor, P. (1979) Stimulation effect of neurotransmitters on the aromatization of testosterone by Sertoli cell-enriched cultures. Molec. cell. Endocr. 13, 241-253.

Verhoeven, G., Cailleau, J. \& de Moor, P. (1980) Desensitization of cultured rat Sertoli cells by follicle-stimulating hormone and by L-isoproterenol. Molec. cell. Endocr. 20, 113-126.

Received 16 June 1983 